DOI: $10.21802 /$ artm.2020.2.14.32.

UDC 616.6-006:577.213/.216

\title{
THE IMPACT OF BODY MASS INDEX ON ASSOCIATION BETWEEN ANRIL GENE POLYMORPHISM AND RENAL CELL CARCINOMA DEVELOPMENT
}

\author{
A.D. Volkogon ${ }^{1}$, V.Yu. Harbuzova ${ }^{2}$, A.V. Ataman ${ }^{3}$ \\ Sumy State University, Sumy, Ukraine: \\ ${ }^{1}$ Department of Surgery and Oncology, \\ ORCID ID: 0000-0003-0835-0657, e-mail:volkogon_andrei@ukr.net; \\ ${ }^{2}$ Scientific Laboratory of Molecular Genetic Research, \\ ORCID ID: 0000-0001-7183-6997,e-mail:v.garbuzova@med.sumdu.edu.ua; \\ ${ }^{3}$ Department of Physiology and Pathophysiology with Course of Medical Biology, \\ ORCID ID: 0000-0002-1941-740X, e-mail:ataman@med.sumdu.edu.ua
}

\begin{abstract}
The aim of the study was to investigate the association between rs4977574 polymorphism of the long non-coding RNA ANRIL gene and renal cell carcinoma development depending on body mass index (BMI).

Materials and methods of the research. The venous blood of 101 patients with clear cell renal cell carcinoma (CCRCC) and 100 individuals without cancer history was used for the study. Venous blood leukocyte DNA was extracted using commercial GeneJET Whole Blood Genomic DNA Purification Mini Kit (Thermo Fisher Scientific, USA). Genotyping of ANRIL gene rs4977574 polymorphism was performed by Real-time PCR method using TaqMan assay C_31720978_30. The reaction was performed on Quant Studio 5 DX Real-Time (Applied Biosystems, USA). Obtaine data was analyzed using SPSS software package (version 17.0). The mean values between two groups were compared using Student's t-test, between three groups - using one-way ANOVA followed by Bonferroni post-hoc test. The risk of CCRCC onset depending on particular rs4977574-genotype was calculated using binary and multivariate logistic regression under different models of inheritance. $P$ values $<0.05$ were considered as statistically significant.

Results of research. The analysis of results in total sample showed no difference in rs4977574-genotypes distribution between control and cancer groups $(\mathrm{P}=0.216)$. This difference was almost significant $(\mathrm{P}=0.053)$ in individuals with BMI $<25 \mathrm{~kg} / \mathrm{m}^{2}$. However, in persons with BMI $\geq 25 \mathrm{~kg} / \mathrm{m}^{2}$ the rs 497757 -genotypes frequency was significantly different between patients with renal cancer and control subjects $(\mathrm{P}=0.002)$. It was revealed that minor allele $\mathrm{G}$ has a protective effect for CCRCC occurrence in subjects with $\mathrm{BMI}<25 \mathrm{~kg} / \mathrm{m}^{2}(\mathrm{OR}=0.300 ; \mathrm{P}=0.045$ - for dominant model of inheritance). Significant results were also preserved after adjusting for sex, age and smoking habit $(\mathrm{OR}=$ $0.169 ; \mathrm{P}=0.031)$. The analysis of overweight individuals showed that the minor G-allele of ANRIL gene rs 4977574 polymorphism, on the contrary, increased the CCRCC risk $(\mathrm{OR}=4,552 ; \mathrm{P}=0.001-$ for dominant model; $\mathrm{OR}=2.036$; $\mathrm{P}=0.041$ - for super-dominant model). The statistical significance of results was also maintained after adjusting for sex, age and smoking $(\mathrm{OR}=4.202 ; \mathrm{P}=0.030$ - for dominant model; $\mathrm{OR}=3.785 ; \mathrm{P}=0.023$ - for super-dominant model). It was also found that BMI $\left(27.5 \pm 4.2 \mathrm{~kg} / \mathrm{m}^{2}\right)$ in CCRCC patients with minor G-allele (genotypes AG and GG) was higher compared to AA-homozygotes $\left(25.2 \pm 4.3 \mathrm{~kg} / \mathrm{m}^{2} ; \mathrm{P}=0.028\right)$.

Conclusions. BMI affects the nature of association between ANRIL gene rs4977574 polymorphism and CCRCC development. Thus, the minor G-allele reduces the CCRCC risk in persons with normal weight. However, in persons with overweight, G-allele is associated with increased CCRCC risk. Also, there is link between ANRIL gene rs4977574 polymorphism and BMI in CCRCC patients. The BMI in minor G-allele carriers is higher compared to AAhomozygotes.
\end{abstract}

Keywords: gene polymorphism, ANRIL, kidney cancer, body mass index.

Introduction. Kidney cancer is ranked $16^{\text {th }}$ in the world among all malignant tumor forms, causing more than 175,000 deaths annually [1]. Wherein, renal cell carcinoma (RCC) accounts for about $95 \%$ cases of all kidney malignant tumors [2]. Therefore, the accurate diagnostics, personalized treatment, and early RCC prevention are the great scientific and social-medical issues.

Numerous experimental studies have shown that long non-coding RNAs (lncRNAs) play the major role in the onset and progression of various tumors, realizing molecular regulation of cell division and transformation [3]. Special attention is now given to IncRNA ANRIL (Antisense Non-coding RNA in the INK4 Locus), also known as CDKN2B-AS1. ANRIL gene is localized within gene cluster that encodes the amino acid sequence of tumor suppressor proteins: p14ARF, p15INK4b and p16INK4a. ANRIL overexpression has been shown to inhibit these proteins activity, which causes genomic instability and promotes tumor progression [4].

The number of reports regarding the IncRNA ANRIL involvement in different malignant tumors emergence have been published. ANRIL has been found to be overexpressed in gastric cancer [5], prostate cancer [6], bladder cancer [7], and squamous cell carcinoma of esophagus [8]. The association between ANRIL gene polymorphisms with breast cancer [9], lung cancer [10], optical glioma [11], multiple myeloma [12], and prostate cancer [13] development has been established. However, 
no studies have yet been conducted to investigate the ANRIL role in kidney cancer development.

Recent large-scale population studies have shown that body mass index (BMI) is the important factor of occurrence, progression and treatment success of number malignant tumors, including kidney cancer [14]. It was revealed that BMI increasing by 1 unit leads to increasing of RCC risk development by approximately $4 \%$ [15]. At the same time, the risk of RCC mortality increased by $5 \%$ with each $\mathrm{kg} / \mathrm{m}^{2}$ [16]. In addition, it has been shown that low ANRIL promoter methylation at birth is associated with obesity in children [17]. Moreover, ANRIL transcripts inhibition is known to reduce the expression of genes involved in glucose and fatty acid metabolism [18].

Rationale for the study. Thus, given the significant role of lncRNA ANRIL in tumorigenesis, its possible involvement in energy metabolism regulation, and significant influence of BMI on malignant tumors emergence and progression, it makes sense to analyze the impact of ANRIL gene polymorphisms on RCC development. This will improve the diagnostic algorithm for kidney cancer and allow recognizing the patients of risk groups in the future.

The purpose of the study was to investigate the association between lncRNA ANRIL gene rs4977574 polymorphism and RCC development depending on BMI.

Material and methods. The venous blood of 101 patients (42 women and 59 men) with clear cell renal cell carcinoma (CCRCC) and 100 persons (34 women and 66 men) without oncology history was used for study. Patients were treated at Sumy Regional Clinical Oncology Hospital from 2005 to 2016. The morphological diagnosis of CCRCC was established according to European Association of Urology (EAU) Guidelines [17]. All subjects had II stage of kidney cancer according to TNM-classification.

The study was conducted in compliance with Council of Europe Convention on Human Rights and Biomedicine, the Declaration of Helsinki, and Order of the Ministry of Health of Ukraine № 690 (23.09.2009). All individuals signed the informed consent for genetic test. The study protocol was approved by the Ethic

Committee of the Medical Institute of Sumy State University (number (№3/05.12.11).

DNA from venous blood leukocytes was extracted using GeneJET Whole Blood Genomic DNA Purification Mini Kit (Thermo Fisher Scientific, USA).

Genotyping of $A N R I L$ gene rs4977574 polymorphism was performed by real time polymerase chain reaction (Real-Time PCR) using TaqMan Assay C_31720978_30. The reaction was conducted in Quant Studio 5 DX Real-Time instrument ("Applied Biosystems", USA). The amplification reaction consisted of initial 10 -minute denaturation $\left(95^{\circ} \mathrm{C}\right)$ followed by 45 cycles of amplification for $15 \mathrm{~s}\left(95^{\circ} \mathrm{C}\right)$ and $30 \mathrm{~s}\left(60^{\circ} \mathrm{C}\right)$.

Statistical analysis of obtained data was performed using SPSS software package (version 17.0). Categorical variables are presented as absolute and percentage values; quantitative data are presented as $\mathrm{M} \pm$ SD (Shapiro-Wilk test was used to check the distribution normality). The mean values between two groups were compared using the Student's t-test, between three groups - using one-way ANOVA followed by Bonferroni posthoc test. Pearson's $\chi^{2}$ test was used to asses the rs4977574 genotypes distribution between comparison groups and its deviation from Hardy-Weinberg equilibrium. The risk of CCRCC onset depending on particular rs4977574 genotype was calculated using binary logistic regression under different models of inheritance. Sex, age, and smoking habit were used as covariates for multivariable logistic regression. Bioinformatic analysis was performed using HaploReg v4 resource. $\mathrm{P}$ values $<0.05$ were considered as statistically significant.

Results. The results of ANRIL gene rs4977574 polymorphism genotyping both in general group and in subgroups stratified by BMI are presented in table 1 . It was revealed no significant difference in rs4977574 genotypes distribution between control and experimental individuals in general group $(\mathrm{P}=0.216)$. However, this difference was practically significant in persons with $\mathrm{BMI}<25 \mathrm{~kg} / \mathrm{m}^{2}(\mathrm{P}=0.053)$. Additionally, the genotypes frequency of $A N R I L$ gene rs4977574 locus differed significantly between patients with CCRCC and control subjects in overweight subgroup (BMI $\left.\geq 25 \mathrm{~kg} / \mathrm{m}^{2}\right)(\mathrm{P}=$ 0.002).

Table 1

The distribution of $A N R I L$ gene rs4977574 polymorphism genotypes in comparison groups

\begin{tabular}{|c|c|c|c|c|c|}
\hline \multirow{2}{*}{ Group } & \multirow{2}{*}{$\mathrm{n}$} & \multicolumn{3}{|c|}{ Genotype } & \multirow{2}{*}{$\mathrm{P}$} \\
\hline & & $\mathrm{AA}(\%)$ & $\mathrm{AG}(\%)$ & GG $(\%)$ & \\
\hline \multicolumn{6}{|c|}{ General group } \\
\hline Control & 100 & $32(32.0)$ & $44(44.0)$ & $24(24.0)$ & \multirow{2}{*}{0.216} \\
\hline CCRCC & 101 & $22(21.8)$ & $55(54.5)$ & $24(23.8)$ & \\
\hline \multicolumn{6}{|c|}{ BMI $<25 \mathrm{~kg} / \mathrm{m}^{2}$} \\
\hline Control & 30 & $5(16.7)$ & $16(53.3)$ & $9(30.0)$ & \multirow{2}{*}{0.053} \\
\hline CCRCC & 35 & $14(40.0)$ & $17(48.6)$ & $4(11.4)$ & \\
\hline \multicolumn{6}{|c|}{ BMI $\geq 25 \mathrm{~kg} / \mathrm{m}^{2}$} \\
\hline Control & 70 & $27(38.6)$ & $28(40.0)$ & $15(21.4)$ & \multirow{2}{*}{0.002} \\
\hline CCRCC & 66 & $8(12.1)$ & $38(57.6)$ & $20(30.3)$ & \\
\hline
\end{tabular}

Note: CCRCC - clear cell renal cell carcinoma; BMI - body mass index; $\mathrm{n}$ - number of persons in subgroup; $\mathrm{P}$ - statistical probability index determined by Pearson's $\mathrm{x}^{2}$ criterion. 
The results of logistic regression analysis are presented in table 2. It was found that minor allele $\mathrm{G}$ has the protective value for CCRCC development in persons with $\mathrm{BMI}<25 \mathrm{~kg} / \mathrm{m}^{2}\left(\mathrm{OR}_{\mathrm{c}}=0.300 ; 95 \% \mathrm{CI}=0.093-\right.$ $0.971 ; \mathrm{P}_{\mathrm{c}}=0.045$ - under dominant model). Significant results were also maintained after adjusting for sex, age and smoking habit $\left(\mathrm{OR}_{\mathrm{adj}}=0.169 ; 95 \% \mathrm{CI}=0.033\right.$ $0.852 ; \mathrm{P}_{\mathrm{adj}}=0.031-$ under dominant model). The analysis of overweight people showed that minor G-allele of ANRIL gene rs4977574 polymorphism, on contrary, in- creases the CCRCC onset risk $\left(\mathrm{OR}_{\mathrm{c}}=4.552 ; 95 \% \mathrm{CI}=\right.$ 1.884-10.998; $\mathrm{P}_{\mathrm{c}}=0.001-$ under dominant model; $\mathrm{OR}_{\mathrm{c}}=$ $2.036 ; 95 \% \mathrm{CI}=1.028-4.032 ; \mathrm{P}_{\mathrm{c}}=0.041$ - under superdominant model). The statistical significance of obtained results was also maintained after adjustment for sex, age and smoking $\left(\mathrm{OR}_{\mathrm{adj}}=4.202 ; 95 \% \mathrm{CI}=1.152-15.334 ; \mathrm{P}_{\mathrm{adj}}\right.$ $=0.030-$ under dominant model; $\mathrm{OR}_{\mathrm{adj}}=3.785 ; 95 \% \mathrm{CI}$ $=1.197-11.971 ; \mathrm{P}_{\mathrm{adj}}=0.023-$ under super-dominant model).

Table 2

Analysis of $\boldsymbol{A N R I L}$ gene rs4977574-genotypes association with CCRCC development depending on BMI

\begin{tabular}{|c|c|c|c|c|}
\hline Model & $\mathrm{P}_{\mathrm{c}}$ & $\mathrm{OR}_{\mathrm{c}}(95 \% \mathrm{CI})$ & $P_{\text {adj }}$ & $\mathrm{OR}_{\mathrm{adj}}(95 \% \mathrm{CI})$ \\
\hline \multicolumn{5}{|c|}{ BMI $<25 \mathrm{~kg} / \mathrm{m}^{2}$} \\
\hline Dominant & 0.045 & $0.300(0.093-0.971)$ & 0.031 & $0.169(0.033-0.852)$ \\
\hline Recessive & 0.071 & $0.301(0.082-1.106)$ & 0.073 & $0.167(0.023-1.183)$ \\
\hline Super-dominant & 0.702 & $0.826(0.311-2.195)$ & 0.590 & $0.668(0.154-2.898)$ \\
\hline \multicolumn{5}{|c|}{$\mathrm{BMI} \geq 25 \mathrm{~kg} / \mathrm{m}^{2}$} \\
\hline Dominant & 0.001 & $4.552(1.884-10.998)$ & 0.030 & $4.202(1.152-15.334)$ \\
\hline Recessive & 0.239 & $1.594(0.734-3.462)$ & 0.598 & $0.710(0.199-2.531)$ \\
\hline Super-dominant & 0.041 & $2.036(1.028-4.032)$ & 0.023 & $3.785(1.197-11.971)$ \\
\hline
\end{tabular}

Note: CCRCC - clear cell renal cell carcinoma; BMI - body mass index; 95\% CI - 95\% confidence interval; $\mathrm{P}_{\mathrm{c}}-$ crude $\mathrm{P}$ (without adjusting for covariats); $\mathrm{OR}_{\mathrm{c}}-$ crude odds ratio; $\mathrm{P}_{\mathrm{adj}}-\mathrm{P}$ after adjusting for sex, age and smoking; $\mathrm{OR}_{\mathrm{adj}}$ - adjusted odds ratio.

Then we have analyzed the possible association between ANRIL gene rs4977574 polymorphic site and BMI only in CCRCC subgroup. The results of rs4977574 genotypes distribution analysis between CCRCC patients with normal BMI and overweight are shown in table 3. It was found that genotypes AG and GG occur much more frequently in individuals with $\mathrm{BMI} \geq 25 \mathrm{~kg} / \mathrm{m}^{2}$, than in patients with $\mathrm{BMI}<25 \mathrm{~kg} / \mathrm{m}^{2}(\mathrm{P}=0.003)$.

Table 3

The distribution of $A N R I L$ gene rs4977574 polymorphism genotypes in CCRCC patients depending on BMI

\begin{tabular}{|c|c|c|c|c|c|}
\hline \multirow{2}{*}{ BMI } & \multirow{2}{*}{$\mathrm{n}$} & \multicolumn{3}{|c|}{ Genotype } & \multirow{2}{*}{ P } \\
\cline { 3 - 5 } & & AA (\%) & AG (\%) & GG (\%) & \\
\hline$<25 \mathrm{~kg} / \mathrm{m}^{2}$ & 35 & $14(40.0)$ & $17(48.6)$ & $4(11.4)$ & \multirow{2}{*}{0.003} \\
\hline$\geq 25 \mathrm{~kg} / \mathrm{m}^{2}$ & 66 & $8(12.1)$ & $38(57.6)$ & $20(30.3)$ & \\
\hline
\end{tabular}

Note: CCRCC - clear cell renal cell carcinoma; BMI - body mass index; $n$ - number of persons in subgroup;

$\mathrm{P}$ - statistical probability index determined by Pearson's $\mathrm{x}^{2}$ criterion.

In addition, we have studied the dependence of BMI on rs4977574-genotypes in CCRCC patients (Table 4). It was revealed that BMI was significantly higher in minor G-allele carriers (AG- and GG-genotypes) compared to AA-homozygotes $(\mathrm{P}=0.028)$.

The link between BMI and $A N R I L$ gene rs4977574-genotypes among CCRCC patients $\left(\mathrm{kg} / \mathrm{m}^{2}\right)$

Table 4

\begin{tabular}{|c|c|c|c|c|}
\hline Model & \multicolumn{3}{|c|}{ Genotype } & $\mathrm{P}$ \\
\hline \multirow{3}{*}{ Codominant } & $\mathbf{A A}$ & AG & GG & \multirow{3}{*}{0.090} \\
\hline & $\mathrm{n}=22$ & $\mathrm{n}=55$ & $\mathrm{n}=24$ & \\
\hline & $25.2 \pm 4.3$ & $27.5 \pm 4.6$ & $27.6 \pm 3.4$ & \\
\hline \multirow{3}{*}{ Dominant } & $\mathbf{A A}$ & \multicolumn{2}{|c|}{$\mathbf{A G}+\mathbf{G G}$} & \multirow{3}{*}{0.028} \\
\hline & $\mathrm{n}=22$ & & & \\
\hline & $25.2 \pm 4.3$ & & & \\
\hline \multirow{3}{*}{ Recessive } & GG & & & \multirow{3}{*}{0.458} \\
\hline & $\mathrm{n}=24$ & & & \\
\hline & $27.6 \pm 3.4$ & & & \\
\hline \multirow{3}{*}{ Super-dominant } & AG & & & \multirow{3}{*}{0.242} \\
\hline & $\mathrm{n}=55$ & & & \\
\hline & $27.5 \pm 4.6$ & & & \\
\hline
\end{tabular}

Note: CCRCC - clear cell renal cell carcinoma; BMI - body mass index; $n$ - number of persons in subgroup; $\mathrm{P}$ - statistical probability index determined by Student's $t$-criterion (for dominant, recessive and super-dominant inheritance models) and by Fisher's F-criterion (for codominant inheritance model). 
Discussion. The lncRNA ANRIL gene (official gene name is $C D K N 2 B-A S 1)$ is located on the short arm of $9^{\text {th }}$ chromosome $(9 \mathrm{p} 21.3)$ within the gene cluster INK4b-ARF-INK4a. As of April 2020, there are 32,759 nucleotide variations in ANRIL gene (according to NCBI).

The results of several case-control studies have shown the relation between $A N R I L$ gene polymorphisms and various malignant tumors development. The TCGAhaplotype (alleles are located within rs1333045, rs1333048 rs4977574, and rs10757278 loci) has been found to be associated with increased breast cancer risk in Iranian women [9]. The rs2151280 polymorphism increases the optic glioma risk in patients with type 1 neurofibromatosis [11] and is associated with relapse in patients with multiple myeloma [12]. Moreover, the rs1011970 single-nucleotide polymorphism (SNP) of ANRIL gene is linked to treatment effectiveness of lung cancer patients [10]. It is suggested that mentioned SNPs may affect the formation of some ANRIL splicing variants and, thus, alter the expression of INK4b-ARF-INK4a genetic locus.

The rs4977574 polymorphism is located within $16^{\text {th }}$ intron of $A N R I L$ gene (103785th position). The results of bioinformatic analysis using HaploReg v4 resource revealed that rs4977574 locus changes the nucleotide structure of binding site for C-ets- 1 and glucocorticoid receptor. These transcription factors are known to be involved in kidney cancer development and progression [19]. Therefore, it can be assumed that rs4977574 polymorphic site is involved in RCC pathogenesis through altering the effect of these proteins on $A N R I L$ expression.

Our results revealed that $A N R I L$ gene rs 4977574 polymorphism is associated with CCRCC onset, but this relationship depends on BMI. Thus, it was found that minor G-allele reduces the CCRCC risk in individuals with BMI $<25 \mathrm{~kg} / \mathrm{m}^{2}$, whereas in overweight people, the $\mathrm{G}$-allele, on contrary, increases the risk of kidney cancer development. There is only one study devoted to link between rs4977574 SNP and development of genitourinary system cancer. Taheri et al. have studied the possible relation between the prostate tumors and ANRIL gene polymorphisms among Iranian men [13]. The rs4977574, rs1333048, and rs10757278 sites were found to be associated with the risk of prostate cancer and prostate benign hyperplasia development.

In addition to comparative analysis between the study and control groups, we also have tested the relation between $A N R I L$ gene polymorphism and BMI separately in CCRCC patients. Patients with rs4977574-G allele have been shown to have significantly higher BMI than patients with rs4977574-AA genotype. It is known, than lncRNA ANRIL influences the activity of genes involved in energy metabolism, in particular adiponectin-1 receptor (ADIPOR1) and vesicle-associated membrane protein-3 (VAMP3) [18]. Also there is an association between degree of $\mathrm{CpG}$ sites methylation of ANRIL gene promoter and obesity development in children [17]. Thus, it can be assumed that $A N R I L$ genetic polymorphism is also capable of BMI affecting in adults.

This can be confirmed by GWAS (genome wide analysis) results, which showed the association between
ANRIL gene rs4977574 polymorphic site and myocardial infarction risk [20]. In addition, the meta-analysis of 23 publications also has revealed strong association of rs4977574 polymorphism with coronary heart disease development [21]. Since overweight is a strong risk factor for cardiovascular disease, ANRIL may be exerting its influence on these diseases pathogenesis precisely by impairment of carbohydrate and lipid metabolism.

Thus, there is reason to believe that ANRIL gene rs4977574 SNP leads to CCRCC development in overweight individuals by modulating the interaction between ANRIL and protein tumor suppressors, as well as by disrupting of lipid and carbohydrate metabolism with subsequent development of overweight and obesity. However, the question of rs4977574-G allele protective effect in persons with normal weight remains unanswered. Further experimental and clinical studies will shed more light on this issue.

\section{Conclusions:}

1. The association between ANRIL gene rs4977574 polymorphism and CCRCC onset depends on BMI. The minor G-allele reduces the CCRCC risk in individuals with $\mathrm{BMI}<25 \mathrm{~kg} / \mathrm{m}^{2}$, however, the G-allele is related to increased CCRCC development risk in individuals with $\mathrm{BMI} \geq 25 \mathrm{~kg} / \mathrm{m}^{2}$.

2. There is a link between $A N R I L$ gene rs4977574 polymorphism and BMI in CCRCC patients. The BMI is higher in minor G-allele carriers compared to AAhomozygotes.

Prospects for further research. The following studies will investigate the role of ANRIL gene polymorphisms in the emergence and progression of other genitourinary system malignant tumors in individuals with various risk factors.

\section{References:}

1. Bray F, Ferlay J, Soerjomataram I, Siegel RL, Torre LA, Jemal A. Global cancer statistics 2018: GLOBOCAN estimates of incidence and mortality worldwide for 36 cancers in 185 countries. CA Cancer J Clin. 2018; 68(6):394-424.

2. Hsieh JJ, Purdue MP, Signoretti S, Swanton C, Albiges L, Schmidinger M, et al. Renal cell carcinoma. Nat Rev Dis Primers. 2017; 3:17009. doi: 10.1038/nrdp.2017.9.

3. Schmitt AM, Chang HY. Long Noncoding RNAs in Cancer Pathways. Cancer Cell. 2016; 29(4):452-463. doi: 10.1016/j.ccell.2016.03.010.

4. Kong Y, Hsieh CH, Alonso LC. ANRIL: A lncRNA at the CDKN2A/B Locus With Roles in Cancer and Metabolic Disease. Front Endocrinol (Lausanne). 2018; 9:405. doi: 10.3389/fendo.2018.00405.

5. Liu $P$, Zhang $M$, Niu Q, Zhang F, Yang $Y$, Jiang $X$. Knockdown of long non-coding RNA ANRIL inhibits tumorigenesis in human gastric cancer cells via microRNA-99a-mediated down-regulation of BMI1. Braz J Med Biol Res. 2018; 51(10):e6839. doi: 10.1590/1414-431X20186839

6. Zhao B, Lu Y, Yang Y, Hu L, Bai Y, Li R, et al. Overexpression of IncRNA ANRIL promoted the proliferation and migration of prostate cancer cells via regulating let-7a/TGF- $\beta 1 /$ Smad signaling pathway. 
Cancer Biomark. 2018; 21(3):613-620. doi: 10.3233/ CBM-170683

7. Zhu H, Li X, Song Y, Zhang P, Xiao Y, Xing Y. Long non-coding RNA ANRIL is up-regulated in bladder cancer and regulates bladder cancer cell proliferation and apoptosis through the intrinsic pathway. Biochem Biophys Res Commun. 2015; 467(2):223-228. DOI: 10.1016/j.bbrc.2015.10.002

8. Fanelli G, Gasparini P, Coati I, Cui R, Pakula H, Chowdhury B. Long-noncoding RNAs in gastroesophageal cancers. Noncoding RNA Res. 2018; 3(4):195-212. doi: 10.1016/j.ncrna.2018.10.001

9. Khorshidi H, Taheri M, Noroozi R, Sarrafzadeh S, Sayad A, Ghafouri-Fard S. ANRIL Genetic Variants in Iranian Breast Cancer Patients. Cell J. 2017; 19(Suppl 1):72-78. doi: 10.22074/cellj.2017.4496

10. Gong WJ, Yin J, Li XP, Fang C, Xiao D, Zhang W, et al. Association of well-characterized lung cancer lncRNA polymorphisms with lung cancer susceptibility and platinum-based chemotherapy response. Tumour Biol. 2016; 37(6):8349-8358. DOI: 10.1007/s 13277-015-4497-5

11. Tritto V, Ferrari L, Esposito S, Zuccotti P, Bianchessi D, Natacci F. Non-Coding RNA and Tumor Development in Neurofibromatosis Type 1: ANRIL Rs2151280 Is Associated with Optic Glioma Development and a Mild Phenotype in Neurofibromatosis Type 1 Patients. Genes (Basel). 2019; 10(11):E892. doi: 10.3390/genes 10110892

12. Poi M, Li J, Sborov D, VanGundy Z, Cho Y, Lamprecht $\mathrm{M}$, et al. Polymorphism in ANRIL is associated with relapse in patients with multiple myeloma after autologous stem cell transplant. Mol Carcinog. 2017; 56(7):1722-1732. doi: 10.1002/mc.22626

13. Taheri M, Pouresmaeili F, Omrani MD, Habibi M, Sarrafzadeh S, Noroozi R, et al. Association of ANRIL gene polymorphisms with prostate cancer and benign prostatic hyperplasia in an Iranian population. Biomark Med. 2017; 11(5):413-422. DOI: 10.2217/bmm-2016-0378

14. Bhaskaran K, Douglas I, Forbes H, dos-Santos-Silva I, Leon DA, Smeeth L. Body-mass index and risk of 22 specific cancers: a population-based cohort study of 5.24 million UK adults. Lancet. 2014; 384(9945):755-65. doi: 10.1016/S0140-6736(14) 60892-8.]

15. Liu X, Sun Q, Hou H, Zhu K, Wang Q, Liu H, et al. The association between BMI and kidney cancer risk: An updated dose-response meta-analysis in accordance with PRISMA guideline. Medicine (Baltimore). 2018; 97(44):e12860. doi: 10.1097/MD. 0000000000012860 .

16. Zhang J, Chen Q, Li ZM, Xu XD, Song AF, Wang LS. Association of body mass index with mortality and postoperative survival in renal cell cancer patients, a meta-analysis. Oncotarget. 2018; 9(17):13959-13970. doi: 10.18632/oncotarget.24210.

17. Lillycrop K, Murray R, Cheong C, Teh A, ClarkeHarris R, Barton S, et al. ANRIL promoter DNA methylation: A perinatal marker for later adiposity. EBioMedicine. 2017; 19:60-72. doi: 10.1016/j.ebiom. 2017.03.037.
18. Bochenek G, Hasler R, Mokhtari N, Konig I, Loos B, Jepsen S, et al. The large non-coding RNA ANRIL, which is associated with atherosclerosis, periodontitis and several forms of cancer, regulates ADIPOR1, VAMP3 and C11ORF10. Hum. Mol. Genet. 2013; 22:4516-4527. doi: 10.1093/hmg/ddt299.

19. Czarnecka A, Niedzwiedzka M, Porta C, Szczylik C. Hormone signaling pathways as treatment targets in renal cell cancer (Review). Int J Oncol. 2016; 48(6):2221-2235. doi: 10.3892/ijo.2016.3460

20. Wang Y, Wang L, Liu X, Zhang Y, Yu L, Zhang F, et al. Genetic variants associated with myocardial infarction and the risk factors in Chinese population. PloS One. 2014; 9:e86332.

21. Huang Y, Ye H, Hong Q, Xu X, Jiang D, Xu L, et al. Association of CDKN2BAS polymorphism rs4977574 with coronary heart disease: a case-control study and a meta-analysis. Int J Mol Sci. 2014; 15:17478-17492.

\section{УДК 616.6-006:577.213/.216}

\section{ВЛИЯНИЕ ИНДЕКСА МАССЫ ТЕЛА НА СВЯЗЬ МЕЖДУ ГЕНЕТИЧЕСКИМ ПОЛИМОРФИЗ- MOM ANRIL И ВОЗНИКНОВЕНИЕМ ПОЧЕЧНО-КЛЕТОЧНОЙ КАРЦИНОМЫ}

\author{
А.Д. Волкогон ${ }^{1}$, В.Ю. Гарбузова ${ }^{2}$, А.В. Атаман ${ }^{3}$ \\ Сумский государственньй университет, \\ г. Сумы, Украина: \\ ${ }^{1}$ кафедра хирургии и онкологии, \\ ORCID ID: 0000-0003-0835-0657, \\ e-mail:volkogon andrei@ukr.net; \\ ${ }^{2}$ научная лаборатория молекулярно-генетических \\ исследований, \\ ORCID ID: 0000-0001-7183-6997, \\ e-mail:v.garbuzova@med.sumdu.edu.ua; \\ ${ }^{3}$ кафедра физиологии и патофизиологии с курсом \\ медииинской биологии, \\ ORCID ID: 0000-0002-1941-740X, \\ e-mail:ataman@med.sumdu.edu.ua
}

Резюме. Целью исследования стало изучение связи между rs4977574-полиморфизмом гена длинной некодирующей $\mathrm{PHK} A N R I L$ и возникновением почечно-клеточной карциномы в зависимости от индекса массы тела (ИМТ).

Материалы и методы. В исследовании использовано венозную кровь 101 больного со светлоклеточной почечно-клеточной карциномой (СКПКК) и 100 человек без онкологических заболеваний в анамнезе. Генотипирование по rs4977574-локусу гена ANRIL выполняли с помощью метода полимеразной цепной реакции в режиме реального времени (Real-time PCR) в присутствии TaqMan assay C_31720978_30. Статистический анализ выполняли с использованием пакета программ SPSS (версия 17.0). Значение $\mathrm{P}<0,05$ считали статистически достоверным.

Результаты. Анализ результатов показал, что разница в распределении rs4977574-генотипов между контрольной и опытной группами в общей 
выборке отсутствовала (Р =0,216). Отдельно у лиц с

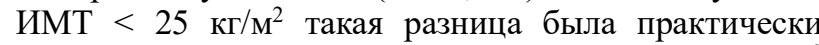

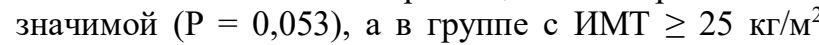
частота генотипов по rs4977574-локусу достоверно отличалась между больными с раком почки и представителями контроля $(\mathrm{P}=0,002)$. С помощью регрессионного анализа было установлено, что у лиц

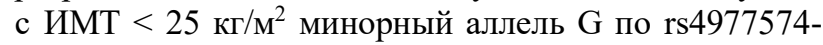
локусу имеет защитное значение в контексте возникновения СКПКК $(\mathrm{OR}=0,169 ; \mathrm{P}=0,031)$. При этом у лиц с избыточным весом G-аллель по rs4977574-сайту, наоборот, повышает риск наступления СКПКК $(\mathrm{OR}=4,202 ; \mathrm{P}=0,030)$. Также было выявлено, что у больных с СКПКК, которые являются носителями минорного аллеля (генотипы

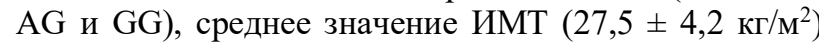
было выше, чем у гомозигот по основному А-аллелю $\left(25,2 \pm 4,3 \kappa \Gamma / \mathrm{M}^{2} ; \mathrm{P}=0,028\right)$.

Выводы. ИМТ влияет на характер связи между полиморфизмом rs4977574 гена ANRIL и возникновением СКПКК. Так, у лиц с нормальным весом минорный $\mathrm{G}$-аллель уменьшает риск наступления СКПКК, а у лиц с избыточным весом аллель $\mathrm{G}$, наоборот, ассоциирован с повышенным риском развития СКПКК.

Ключевые слова: полиморфизм генов, ANRIL, рак почки, индекс массы тела.

\section{УДК 616.6-006:577.213/.216}

\section{ВПЛИВ ІНДЕКСУ МАСИ ТІЛА НА ЗВ'ЯЗОК} МІЖ ГЕНЕТИЧНИМ ПОЛІМОРФІЗМОМ $A N R I L$ ТА ВИНИКНЕННЯМ НИРКОВО-КЛІТИННӦ̈ КАРЦИНОМИ

\author{
А.Д. Волкогон ${ }^{1}$, В.Ю. Гарбузова ${ }^{2}$, О.В. Атаман ${ }^{3}$ \\ Сумський державний університет, м. Суми, Украӥна: \\ ${ }^{1}$ кафедра хірургї̈ та онкологї, \\ ORCID ID: 0000-0003-0835-0657, \\ e-mail:volkogon andrei@ukr.net; \\ ${ }^{2}$ наукова лабораторія молекулярно-генетичних \\ досліджень, \\ ORCID ID: 0000-0001-7183-6997, \\ e-mail:v.garbuzova@med.sumdu.edu.ua; \\ ${ }^{3}$ кафедра фізіології і патофізіології з курсом \\ медичної біології, \\ ORCID ID: 0000-0002-1941-740X, \\ e-mail: ataman@med.sumdu.edu.ua
}

Резюме. Метою дослідження стало вивчення зв'язку між rs4977574-поліморфізмом гена довгої некодуючої РНК ANRIL та виникненням нирковоклітинної карциноми залежно від індексу маси тіла (IMT).

Матеріали та методи. У дослідженні використано венозну кров 101 хворого зі світлоклітинною нирково-клітинною карциномою (СКНКК) та 100 осіб без онкологічних захворювань в анамнезі. Генотипування за rs4977574-поліморфізмом гена $A N R I L$ виконували за допомогою методу полімеразної ланцюгової реакції в режимі реального часу (Real-time PCR) у присутності TaqMan assay C_31720978_30. Статистичний аналіз виконували із використанням пакету програм SPSS (версія 17.0). Значення $\mathrm{P}<0,05$ вважали за статистично достовірні.

Результати. Аналіз результатів показав, що різниця в розподілі rs4977574-генотипів між контрольною та дослідною групами у загальній вибірці була відсутньою $(\mathrm{P}=0,216)$. Окремо в осіб із $\mathrm{IMT}<25$ кг/ $\mathrm{M}^{2}$ така різниця була практично значущою (P = $0,053)$, а в групі з IMT $\geq 25$ кг/ M $^{2}$ частота генотипів за rs4977574-локусом достовірно відрізнялась між хворими із раком нирки та особами контролю $(\mathrm{P}=0,002)$. За допомогою регресійного аналізу було встановлено, що в осіб з IMT $<25$ кг/м ${ }^{2}$ мінорний алель $\mathrm{G}$ за rs4977574-локусом має захисне значення щодо виникнення СКНКК $(\mathrm{OR}=0,169 ; \mathrm{P}=0,031)$. При цьому в осіб із надмірною вагою G-алель за rs4977574-сайтом, навпаки, підвищує ризик настання СКНКК (OR = $4,202 ; \mathrm{P}=0,030)$. Також було виявлено, що у хворих iз СКНКК, які є носіями мінорного алеля (генотипи

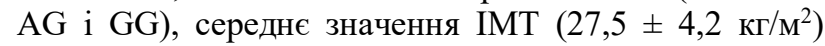
було більшим, ніж у гомозигот за основним А-алелем $\left(25,2 \pm 4,3\right.$ кг/ $\left.\mathbf{M}^{2} ; \mathrm{P}=0,028\right)$.

Висновки. IMT впливає на характер зв'язку між поліморфізмом rs4977574 гена ANRIL та виникненням СКНКК. Так, в осіб з нормальною вагою мінорний G-алель зменшує ризик настання СКНКК, а в осіб з надмірною вагою алель $\mathrm{G}$, навпаки, асоційований із підвищеним ризиком розвитку СКНКК.

Ключові слова: поліморфізм генів, ANRIL, рак нирки, індекс маси тіла.

Стаття надійшла в редакцію 31.03.2020 р. 